\title{
On Effective Combination of Web-based Learning and Autonomous Learning in Higher Vocational College English Teaching ZHANG Lin-lin
}

\author{
Basic Teaching Department, Jilin Railway Technology College, Jilin, Jilin 132002, China
}

10029888@qq.com

\begin{abstract}
Keywords: Web-based Learning; Autonomous Learning; Higher Vocational College English; Effective Combination
\end{abstract}

\begin{abstract}
With the development of internet technology, web is covering almost every higher vocational college in China, which enables students to take advantage of web sources in leaning English. Meanwhile, in the light of Higher Vocational College English Curriculum Basic Requirement (for Trial Implementation), higher vocational English teaching reform in China is cultivating students' autonomous learning ability. Therefore, effective combination of web-based learning and autonomous learning in higher vocational college has practical significance. It is in full conformity with Three-year Implementation Plan on Creative Development of Higher Vocational Education, in which widely existed, movable and personal study methods has been encouraged. Based on related theories, this article made an exploration on how to effectively combine web-based learning with autonomous learning.
\end{abstract}

\section{Introduction}

For ages, traditional teacher-centered English learning has been prominent in higher vocational college English learning, due to less interest in English communicative ability of the students as well as their poor language environment. Teachers spent most of class time in explaining the usage of words and expressions, language points and grammar knowledge, while students just carefully wrote down notes and learnt English passively for the purpose of passing the exam. As a result, the application ability of students is rather dissatisfactory. It is impossible for them to obtain English study ability for future use which became the most serious issue confused English teachers. In 1988, David Nunan proposed the concept of language learning centered on learners, providing a new aspect of English learning. In consequence of that, many countries have regarded cultivating autonomous ability as the key to learning English. With the development of internet technology, web provided convenient and authentic language environment for students. In 2000, Ministry of Education in China enacted Higher Vocational College English Curriculum Basic Requirement (for Trial Implementation), pointing out that “ in higher vocational college English teaching, attention should be paid to innovating and applying actively such modern teaching methods as computer, multi-media and internet technology in addition to activating students' English learning autonomy and enthusiasm.” For this point of view, this article aimed to study the effective combination of web-based learning and autonomous learning in higher vocational college.

\section{Theoretical Foundation}

Theories related to autonomous learning and web-based learning from abroad and home laid firm foundation for combination of these two learning methods.

\section{Autonomous Learning}

The theory of autonomous learning derives from cognitive, humanistic and constructive learning theories. Cognitive theory is a learning theory in terms of psychology that articulates learning takes place in the mind, not in behavior. Huttunen (1986:35) is a cognitive psychologist, who believes that people acquire new information by way of actively participation in the process of learning; furthermore, learning process determines the meaning of new information. It is the learner who selectively reconstructs the new information meaning and eventually integrates the new information 
into the known knowledge for future use. Carl Rogers(1969), a humanistic psychologist, advocates each human is born with a nature potential for learning and promoting autonomous learning. It is not teacher but learner who has the power to decide the learning content, learning process and learning strategy. Learner also has right to participate in the assessment of his/her progress. He points out that learner is not passive information receiver but active builder of information. Constructivism learning theory is a branch of cognitive psychology, which holds that situation, cooperation, conversation and meaning construction are the four elements or the four attributes of learning environment. Constructivism claims that learning is a process in which learners build their knowledge actively rather than accept it passively. As a learning theory, Constructivism attached importance on "learner-centered learning" under the guidance of teachers, and put emphasis on learner's cognitive subject function as well as teachers' guidance function in learning.

Henri Holec firstly applies autonomous learning theory in language learning. In his work, Autonomy and Foreign Language Learning, Holec defined learner autonomy as ability to be responsible for one's own learning" in the learning process, that is to say, the learner is capable of deciding issues related to learning aspects. Little (1991) viewed the autonomous learning as three kinds of capability: "the objective, critical ability, decision-making ability and the ability to take independent action”. Domestic study on autonomous learning started the late 1980s and early 1990s. In recent years more and more English teachers begin to emphasize autonomous learning and apply it to their teaching practice. Pang Weiguo (2003) pointed out that "autonomous learning can be divided into three aspects: first, it is plan and arrangement in advance for one's own learning activities; second, it is supervision, evaluation and feedback to one's actual learning activities; third, it is adjust modification and control to one's own learning activities”.

\section{Web-based Learning}

With the development of internet technology, more and more researchers started to focus on the study of web-based learning from different aspects. They contributed a lot to this field and gave different definitions about web-based language learning. Web-based language learning is a mode of hypermedia-based learning in which the learner makes use of the resources and attributes of the World Wide Web to carry on a meaningful learning situation where learning is supported and cultivated (Khan, 1997). Internet provides a very favorable environment for students to improve ability to autonomous learning. Autonomy can be cultivated through web-based language learning (cited in Liu Shulin, 2004). Researchers home and abroad have compared web-based learning with traditional classroom teaching. Some experts believes that web-based learning result in better learning effect than the traditional one (Sullivan \& Pratt, 1996; Wen Jun,2005).

In comparison with traditional learning, web-based learning has the following advantages. First, web-based learning can overcome the obstacles in scope of time and space of traditional learning. Learners can learn at any time at any place as long as internet is available at their convenience and waste less time in taking vehicles. Second, internet can make personalize learning come true. Without the limitation of learning time, learners can arrange their own learning schedule flexibly and select learning contents satisfying their personal goals. Third, internet also provides learners with convenient communication approaches. Such internet communication tools as email, BBS, MSN, blog, wechat can stimulate learner's desire for using foreign language to communicate with native speakers. Fourth, with the support of sufficient and varied forms of sources, internet enables learners to enjoy a wide range of learning materials such as video, sounds, vivid pictures and so on.

\section{Combination of Autonomous Learning and Web-based Learning}

Studies concerning about autonomous learning and web-based learning have been made by researchers respectively. In fact, there is a close connection between them. In recent years, great importance has been attached to the combination of autonomous learning and web-based teaching, and related achievements have been made. Warschauer (1996) defines the combination of web-based environment and language learning is the most efficient way to cultivate learner autonomy. Appropriately implemented, the web-based learning and teaching can gain equality in class and assist students in achieving a critical learning point. Web-based autonomous language learning creates various and diverse learning opportunities, stimulates the students' motivation, 
attracts learners' interests, strengthen the learning effect for individuals, at the same time, it brings new vitality and energy into the current teaching and learning situation and extends a bright future for language learning. Kulik (1980) made a series of experiments on the functions of computer-assisted language learning in language teaching and drew a conclusion that CALL plays a positive role in teaching languages and facilitates students' achievements much faster than using the traditional teaching method.

The history of web-based teaching in China is not very long. But with the fantastic development of internet technology, it achieved some exploits. Jia Guodong (2003) points out that computer-assisted language learning mode is designed to shift the traditional teaching form from teacher-centered to learner-centered. As a result, the new mode offers more opportunity to the students to shoulder the responsibility of their learning and realize learning autonomy. Huang Ping (2004) considered web-based autonomous learning as "learners use the network, apply and control their own meta-cognition, motivation and behavior to learn network course". Network teaching environment provides students with a student-centered learning environment which is adjust to the constructivism learning theory.” (Yu Liming, Guo Hongjie, 2005).

\section{Effective Combination of Web-based Learning and Autonomous Learning in higher vocational college English Teaching}

This part discusses the ways to combine web-based learning with autonomous learning effectively in higher vocational college English teaching in terms of learning motivation, learning contents, learning plan, learning strategy, learning evaluation and learning environment.

\section{Learning Motivation}

The English level of higher vocational college students is rather low. Although they know the important role English played, they are less interested in English learning because of their weak English ability. Most of the students learn English just for the purpose of passing the exam or obtaining certificate. Brundage and MacKeracher(1980:21-31) indicates that "Adults learn best when novel information is presented through a variety of sensory nodes and experiences, with sufficient repetitions and variations on themes to allow distinctions in patterns to emerge. Therefore, English teachers in higher vocational colleges are expected to utilize wide range of teaching resources provided by internet such as English websites related to all fields, music ,films even internet games which are likely to attract students, and encourage students to apply such internet tools as email, web English corner in order to stimulate students' autonomous motivation.

\section{Learning Content}

At present, students in higher vocational college seldom have the opportunity to select learning content for themselves; they just complete the language tasks arranged by the teachers. The content in text books is designed for all the students in the school. However, higher vocational college students usually have different English proficiency. Thus, specified learning content is not universally appropriate to all the students. With the internet, contents can be selected in accordance with different grades. As Nunnan points out "adult students learn best when they are involved in developing learning objectives for themselves which are congruent with their current and idealized self concept.” Internet provides sufficient enough learning materials for students to select freely.

\section{Learning Plan}

Study plan, is a plan of study for students to use in the process of learning, which aims at developing their creativity and learning ability. Fan Zengmin (2003) states that a study plan should demonstrate students' thoughts of learning. Credited to referent information at abroad and home, internet make it possible for students in higher vocational college to plan learning taking into acco unt of their future prospects.

\section{Learning Strategy}

Training the learning strategies is very vital for the students. For the purpose of leading the students to become more autonomous and more independent, it is necessary to do some learning strategy drill for the learners. Internet provides learners with efficient learning strategies, which enables students in higher vocational college to identify their own preferred learning strategy. 


\section{Learning Evaluation}

Fostering a habit of keeping diary per day or week to evaluate learning process is very crucial to students. During the learning process, students need to adopt their good points and avoid their shortcomings. With the aid of internet tools, it is possible for students to make an online evaluation promptly and correctly. In addition, with the exception of online self-evaluation, there are also native speakers who can help English learner to evaluate their learning in web environment.

\section{Learning Environment}

Many students in higher vocational college never or seldom have a discussion with their teachers and classmates. Autonomous learning does not mean learning alone. Autonomous learning needs interaction and cooperation as well. As known to all, there are affluent resources on the Internet, it is hard to deal with them and complete the tasks in a short time. What's more, in the internet or face-to-face interaction, the students will strengthen the team cooperation spirit.

\section{Summary}

This article discusses on theories and possibility to effectively combine autonomous English learning with web-based learning in higher vocational college English teaching. There is still a long way to develop the students' autonomous learning in web-based English learning context. It is a new challenge for both teachers and learners.

\section{References}

[1] Fan Zengmin. Study on Teching Method Guided by Learning Plan, Qufu Normal University Press. (2003).

[2] Higher Vocational College English Curriculum Basic Requirement (for Trial Implementation), (2000), p.2

[3] Holec, H. Autonomy and Foreign Language Learning [M]. Oxford: Pergason Press. (1981).

[4] Huttunen, L. Towards School. [M]. Finlang,Learner Autonomy in Foreign Language Learning in Senior Secondary OuLou: University of OuLou. (1986).

[5] Jia Guodong. Modern Internet Technology and College English Teaching Mode Reform.(2003)

[6] Khan, B.H. Web-based Instruction. New Jersey: Educational Technology Publications. (1997).

[7] Little, D. Learner Autonomy 1: Definitions, Issues and Problems. Dublin: Authentik. (1991).

[8] Liu Shulin. New Concept of English Teaching. Hefei: Press of University of Science and Technology of China. (2004).

[9] Nunan, D. Research Methods in Language Learning. Shanghai: Shanghai Foreign Language Education Press. (.2001)

[10] Pang Weiguo. Autonomous learning___Principle and Strategy of Learning and Teaching [M]. Shanghai: Huadong Nornal University Press. (2003)

[11]Rogers, C. Freedom to learn: A view of what education might become [M]. Columbus, OH:Charles E.Merrill. (1969).).

[12] Sullivan, N. \& Pratt, E. A Comparative Study of Two ESL Writing Environments: A Computer-assisted Classroom and a Traditional Oral Classroom. System, 29(4): 491-501. (1996) [13] Three-year Implementation Plan on Creative Development of Higher Vocational Education (2014)

[14] Warschauer, M., Turbee, L. \& Roberts, B.S. Computer Learning Networks and Student Empowerment. System, 24:1-14. (1996). 